\title{
Strategic objectives and development plans of beginning farmers
}

\author{
Leena Rantamäki-Lahtinen and Minna Väre \\ MTT Agrifood Research Finland, Economic Research \\ Latokartanonkaari 9, 00790 Helsinki, Finland \\ e-mail: leena.rantamaki-lahtinen@mtt.fi
}

\begin{abstract}
Taking over the management and ownership of a farm contributes positively to farm growth but little is known about how farmers succeed after the starting phase. We analysed how farmers that have recently started their farm enterprises are going to develop their farms and how do they differ from more experienced farmers in some key farm management areas. Data were collected by postal survey from farmers of the Salo region in South-Western Finland. Farmers were categorized into three different groups according to a combination of their age and experience. Farmers who were in the early phase of taking over a farm had better education and better networks than their older counterparts. Younger farmers considered their networks to be more important than did their senior colleagues. The early phase farmer group invested significantly more and had more liabilities than the other two groups. Moreover, early phase farmers were the most active at developing their farms. The late phase farmers were the least active, even when they knew they were going to transfer their farm to next generation within the next few years. Farms should be developed continuously in order to improve the viability of whole farming sector.
\end{abstract}

Key words: consolidation phase, farm management, multivariate data analysis, networks

\section{Introduction}

Starting new businesses and transferring ownership and management of family firms (farms) to upcoming generations are vital for preserving jobs and for the maintaining the overall viability of the countryside. Passing on a firm was found to contribute positively to subsequent growth of the firm after a consolidation phase of some years (Diwisch et al. 2009). The positive effect of succession on farm growth applies especially to the full-time farms (Weiss 1999).

Starting a new rural/farm business is often subsidized by different policy schemes and also by rural development measures. For example, starting aid and early retirement schemes for farmers are crucial facilitating factors for farm transfers (Väre 2007, Hirvi 2004a). Similarly, new firms are subsidized by different sources, such as starting loans, financial aid and extension services. Such schemes have also had a great impact on the profitability, continuity and compatibility of the firms.

However, there is lack of information on how effectively the new farm businesses succeed and develop after the starting phase. There is some research-based information on farm succession. For example, the income structure of young farmers has been analysed (Hirvi 2004b). However, little is known about how farmers develop their farms after taking them over and how well the farmers succeed in the first years after having commenced with their own businesses.

Littunen et al. (1998) studied the success of new firms and the factors that affect them. In their study, the first three years were assumed to be critical in terms of the continuation of a firm. According to those authors, the success or failure of a new firm is strongly affected by the planning of the start-up phase and thus by the characteristics and know-how of the entrepreneur. Similarly, Goldberg (1996) reported that short- and long-term prospects of the industry in addition to the educational background and experience of the successor is also important. Furthermore, Goldberg (1996) suggested that effective successors benefited from multiple mentoring networks (counsellors, advisors, family members).

According to the life-cycle models, a firm develops through so called evolution and revolution phases. Farm succession is a typical example of this. When a farm is transferred to a successor, typically new activities/enterprises are initiated or the old activities are developed or modified (Rantamäki-Lahtinen 2007). For example, about $18 \%$ of the Finnish farms that transferred to the successive generations during the years 2004-2008 changed their main production line. Typically, the farms gave up animal production and concentrated on crop production and it was reported that $63 \%$ of the farms changed their production line (Väre 2010). Similarly, Mäkinen (2010) found that Finnish dairy farmers that were planning farms succession in the near future were likely to give up dairy production 
or start new production line or non-agricultural business. Those late-phase farmers that did not have successor had strategies where they were going to keep current level of production or planned giving up dairy production. Dairy farms that had earlier adopted growth-strategy, were also most growth seeking ones in the future. Recent studies of Inwood and Sharp (2012) and Wheeler et al. (2012) have similar findings from USA and Australia; those farmers who have successors are more likely to develop their farms and those with no successors are more likely to choose stagnation strategy. However, as Wheeler et al. (2012) point out, successions are strongly influenced by farm type and context. What has increased rapidly is uncertainty about the future - in all shapes and forms. This fact affects the decision making of farmers in all ages and phases. There is some evidence from Finnish data that farmers' age does have quite a big influence on what kind of strategies he or she will choose. It is also typical that the farmer's primary option is not to decide between issue whether to quit farming or continue. It is actually to make decision whether to keep 'status quo' i.e. to keep everything as it is or make changes (Kuhmonen 2012).

Most studies on the beginning phase of farming careers focus on the realisation or the process of succession (Kimhi and Lopez 1999) or new entrants into the sector. However, the focus is different in this study. There is a gap in research on how farmers and their strategies change in different phases of life-cyle. In this article we analyse how recently started farmers are going to develop their farms and how do they differ from more experienced farmers in some key farm management areas such as farm and farmer characteristics, strategic objectives and development plans.

\section{Material and methods}

Data were obtained from farmers of the Salo region in South-Western Finland. A questionnaire was sent by post to all of Salo region's farmers ( $\mathrm{N}=1250)$. The respondents posted the completed questionnaires by November 2010. The response rate was $19 \%(\mathrm{~N}=237$ ), which is typical, since there were no follow-up survey.

In the survey, there were a total of 11 questions related to different management principles or strategic objectives of the enterprise. In addition there were questions about the basic information of the farm (including financial information), development plans, success and networks.

The data were analysed by using chi square-test, Kruskall-Wallis test, explorative factor analysis and k-means cluster analysis. The variables were based on existing theories and careful testing of the questionnaires to make sure that the validity of the variables was as good as possible.

\section{Results}

We started the analysis by determining those farmers that were in the entry phase of their farming career. Such a determination is difficult when it is simply based on the age of an entrepreneur or his or her experience. Being 'young' does not necessarily indicate that the farmer is inexperienced as some farmers start farming before they turn 20 and some others start in their 40's. On the other hand, the entrepreneurial experience per se is not sufficient to determine the phase as farmers are in very different situations in their lifespan.

In order to evaluate which phase category each respondent belonged to, cluster analysis was done by using kmeans procedure for two variables: age of the respondent (years) and entrepreneurial experience. Analysis was accomplished by assigning respondents into two to four groups. The combination of three groups was chosen as being optimum (Appendix 1).

The interpretation of a 3 group solution was clear and comparable with the early findings of Nalson (1968; referred by Gasson and Errington 1993) about family development on farm organization. Farmers included in the first group 'early phase' ( $n=64)$ were younger and had the least entrepreneurial experience (Table 1$)$. They also belonged to the group we defined as the 'early phase group'. The second group, 'middle phase', comprised of farmers $(n=86)$ who were middle-aged and who had more entrepreneurial experience than farmers in the early phase group. The third group was named 'late phase' $(n=93)$ and comprised farmers that were older and had the most entrepreneurial experience than either of the two "younger groups". The categories used here differ from those reported by Ondersteijn et al. (2003), who only had two groups of farmers based upon: Those on entry/exit phase and those on the growth/consolidation phase. 
The majority of the 'early phase' group started farming in the 2000's, whereas most of the farmers belonging to the 'middle phase' group started farming at the beginning of 1990's. Farmers of the 'late phase' group started farming in late 1970's or early 1980's. The younger farmers were better educated than their older counterparts: a finding that mirrors Finnish society in general. There were no significant differences between groups for several variables including: income structure of the farm families, the share of the production lines and farm diversification or farm size (personnel and turnover). However, the early phase farmers group had invested significantly more than the others and in addition their liabilities per turnover rate were higher. The result was as expected. The characteristics of the groups are presented in Table 1.

In Salo region, share of plant production farms is over $80 \%$ all farms (Salon kaupunki 2011). This means that the data used represent the farm population on study area pretty well. Unfortunately, it was not possible to classify the study farms by production line since there were less than 5 sample farms in some production lines.

Table 1. Descriptive statistics of farm and farmer characteristics in different groups.

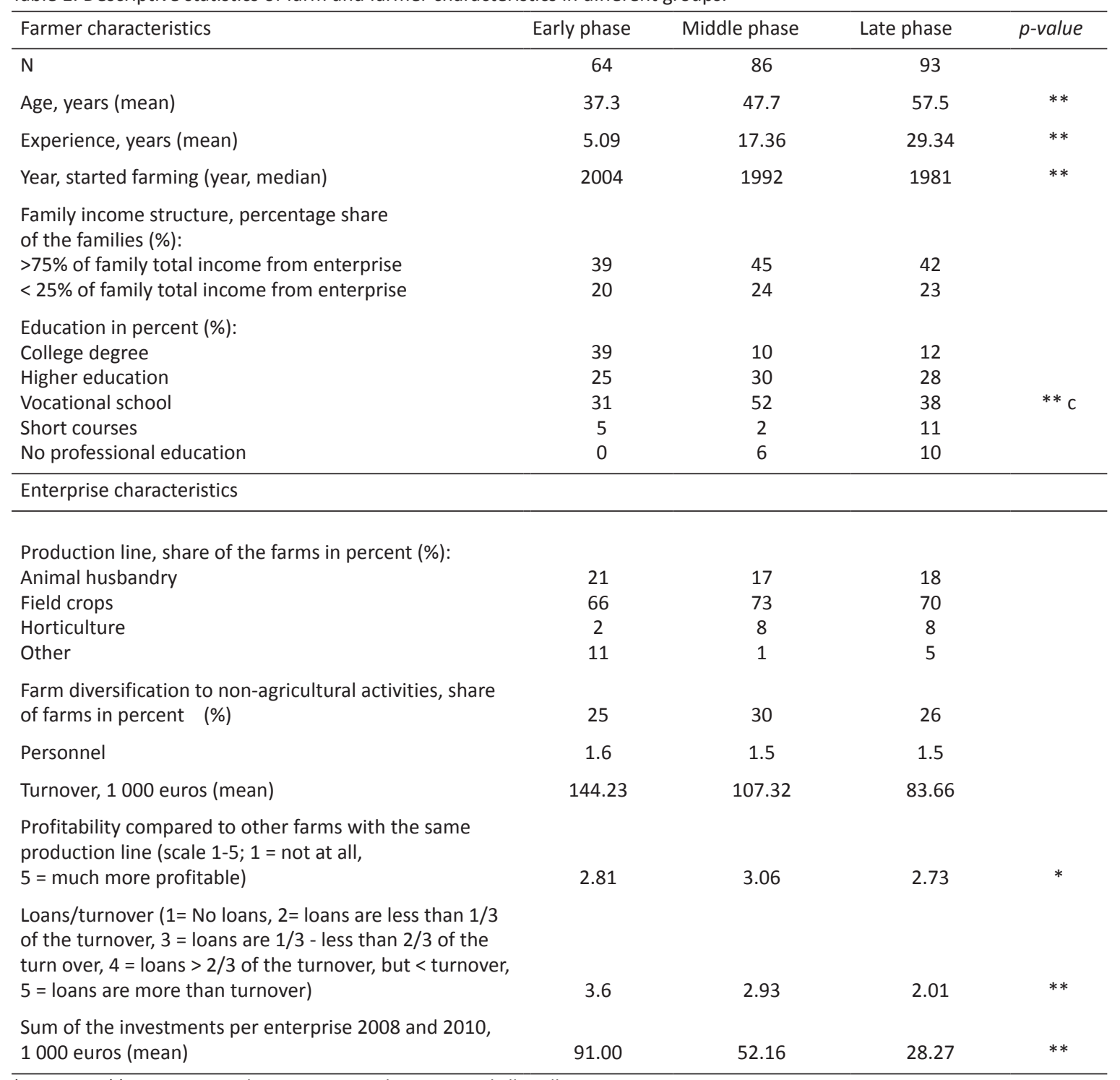

${ }^{*}=p<0.05, * *=p<0.01, \mathrm{c}=$ chi square-test, otherwise Kruskall-Wallis non-parametric test 


\section{Strategic objectives}

In this study, we assumed that farmers have multiple strategic objectives. For instance, it has been found in previous studies that in addition to economic values, many farmers highly value things such as the ability to maintain their lifestyle and good family life (Cuykendal et al. 2002). In the survey, there were a total of 11 questions related to different management principles or strategic objectives of the enterprise. In addition, a question was: how well respondents felt that they had succeeded for achieving those objectives. Questions were evaluated by Likert scale (scores $1-5,1=$ not at all important/achieved and $5=$ very important or achieved very well). An explanatory factor analysis was run for the data concerning the objectives (table 2), and these factor scores were used as variables at the later stages of the analysis (Table 3a). The second question, how farmers had achieved the set goals, was measured by creating sum variables (Table $3 b$ ).

A principal axis factor analysis resulted in a three-factor solution, which accounted for about $49 \%$ of the total variance of the original variables (Appendix 2). The number of factors was defined by using the cut-off point of 1 in Eigen values. An orthogonal Varimax rotation was performed. The rotated factor structure (Table 2) is clear, though some variables had moderate loadings of at least two factors. Factor 1 represented objectives that were related to social and environment responsibility. Factor 2 represents objectives that related to work satisfaction. Factor 3 covers economic objectives, such as profit maximizing, better standard of living and economic profitability. A reliability analysis was conducted. A Cronbachs Alfa $(\alpha)$ value for reliability of 0.75 was obtained for F1, 0.73 for F2 and 0.77 for F3. According to Hair et al. (1998, p.118) the lower limit for $\alpha$ is 0.7 , so reliability of used variables was sufficient for further analysis.

Table 2. Rotated factor matrix for the strategic objectives among farmers in Salo.

\begin{tabular}{|c|c|c|c|}
\hline & $\begin{array}{l}\text { Factor } \\
\text { F1 }\end{array}$ & $\mathrm{F} 2$ & F3 \\
\hline Domestic production & 0.658 & 0.134 & 0.059 \\
\hline Respecting nature & 0.636 & 0.216 & 0.083 \\
\hline Living in the countryside & 0.626 & 0.466 & 0.04 \\
\hline Controlling own life, own wellbeing & 0.561 & 0.25 & 0.25 \\
\hline Continuing family farm & 0.406 & 0.088 & 0.231 \\
\hline Independent work & 0.213 & 0.848 & 0.068 \\
\hline Good quality work & 0.31 & 0.578 & 0.161 \\
\hline Being able to get independent income & 0.173 & 0.542 & 0.228 \\
\hline Better standard of living & 0.174 & 0.088 & 0.779 \\
\hline Profit maximising & 0.065 & 0.104 & 0.715 \\
\hline Economic profitability & 0.156 & 0.183 & 0.623 \\
\hline
\end{tabular}

Early phase farmers had somewhat similar objectives to those of the other two groups. However, the early phase group appreciated social and environmental aspects and work satisfaction less than the others. On the other hand, the economic objectives were more important to them (Table 3a). Farmers were asked how well they had achieved their strategic objectives. In general, farmers did not achieve their economic objectives (Table 3b).

Farmers' views were more positive in other aspects. Early phase farmers indicated that their success in all measured areas was weaker than that of other groups. Early phase farmers had not achieved their economic objectives at the time of the survey. However, what was especially worrying was that many late phase farmers indicated that their economic success was poor, which would be expected to have a detrimental affect on future successions in addition to affecting the current situation adversely.

Also, the poor market situation and unfavorable price relations during the time of survey have to been taken into account when valuing farmers views on their economic performance and farm profitability. In 2009-2010, the financial situation tightened especially on the pig and cereal farms (Niemi and Ahlstedt 2011). Because of the large share of crop and plant production farms, this may have caused financial problems and affected the farmers' opinions especially on study area. In earlier studies (Väre 2007) producer prices have been found to affect also the likelihood of farm successions. Thus, the increasing price volatility and changes in market prices may be considered as a problem for farms developing their production or planning succession. 
Table 3a. Mean factor scores for strategic objectives of farmers in the different phases.

\begin{tabular}{llll}
\hline & Early phase & Middle phase & Late phase \\
\hline Social and environment responsibility-objectives & -0.06 & -0.02 & 0.04 \\
Work satisfaction-objectives & -0.24 & 0.12 & 0.06 \\
Economic-objectives & 0.15 & 0.06 & -0.17 \\
\hline$*$
\end{tabular}

$*=p<0.05$, Kruskall-Wallis non-parametric test

Table 3b. Mean sum variables of the performance of farmers in the different phases for different strategic objectives.

\begin{tabular}{llll}
\hline & Early phase & Middle phase & Late phase \\
\hline $\begin{array}{l}\text { Performance: achieving social and environmental } \\
\text { responsibility-objectives }\end{array}$ & 3.60 & 3.76 & 3.80 \\
Performance: achieving work satisfaction-objectives & 3.56 & 3.74 & 3.87 \\
\hline Performance: achieving economic-objectives & 2.79 & 2.89 & 2.94 \\
\hline
\end{tabular}

$*=p<0.05$, Kruskall-Wallis non-parametric test

\section{Development plans}

In the last part of the study we analyzed how the development plans differed between phases (Table 4). In the survey, farmers were asked how they were going to develop their enterprise in the next five years. In nearly all aspects farmers in the early phase were more eager to develop their farm than farmers belonging to the other two phase groups. This result is in line with the earlier findings on farm growth at the entry stage (Weiss 1999). However, as shown in the Figure 1, even farmers in the early phase did not see development potential in most of the development paths covered in the questionnaire. The most common development plans were somewhat traditional: introducing new production methods and increasing capacity or farm co-operation.

Table 4. The probability to introduce development plans in the farm among farmers in the different phases $(1=$ very low probability to do this in my farm, $5=$ very high probability).

\begin{tabular}{|c|c|c|c|c|}
\hline & Early phase & Middle phase & Late phase & $p$-value \\
\hline Finding more clients & 2.85 & 2.36 & 1.90 & $* *$ \\
\hline Introducing new production methods & 3.33 & 2.81 & 2.32 & $* *$ \\
\hline Introducing new logistic or channels & 2.98 & 2.65 & 2.08 & $* *$ \\
\hline Increasing capacity & 3.30 & 2.63 & 2.02 & $* *$ \\
\hline Increasing labor & 236 & 1.87 & 1.51 & $* *$ \\
\hline Increasing co-operation with other farms or firms & 3.05 & 2.58 & 2.01 & $* *$ \\
\hline Outsourcing/ buying more contract work & 2.73 & 2.13 & 1.83 & $* *$ \\
\hline New products/services & 3.19 & 2.63 & 2.23 & $* *$ \\
\hline New production lines/lines of business & 2.55 & 2.2 & 1.78 & $* *$ \\
\hline Succession & 1.13 & 1.39 & 2.30 & $*$ \\
\hline Re-focusing & 2.01 & 2.12 & 2.56 & $* *$ \\
\hline
\end{tabular}

${ }^{*}=p<0.05,{ }^{* *}=p<0.01$, Kruskall-Wallis non-parametric test 


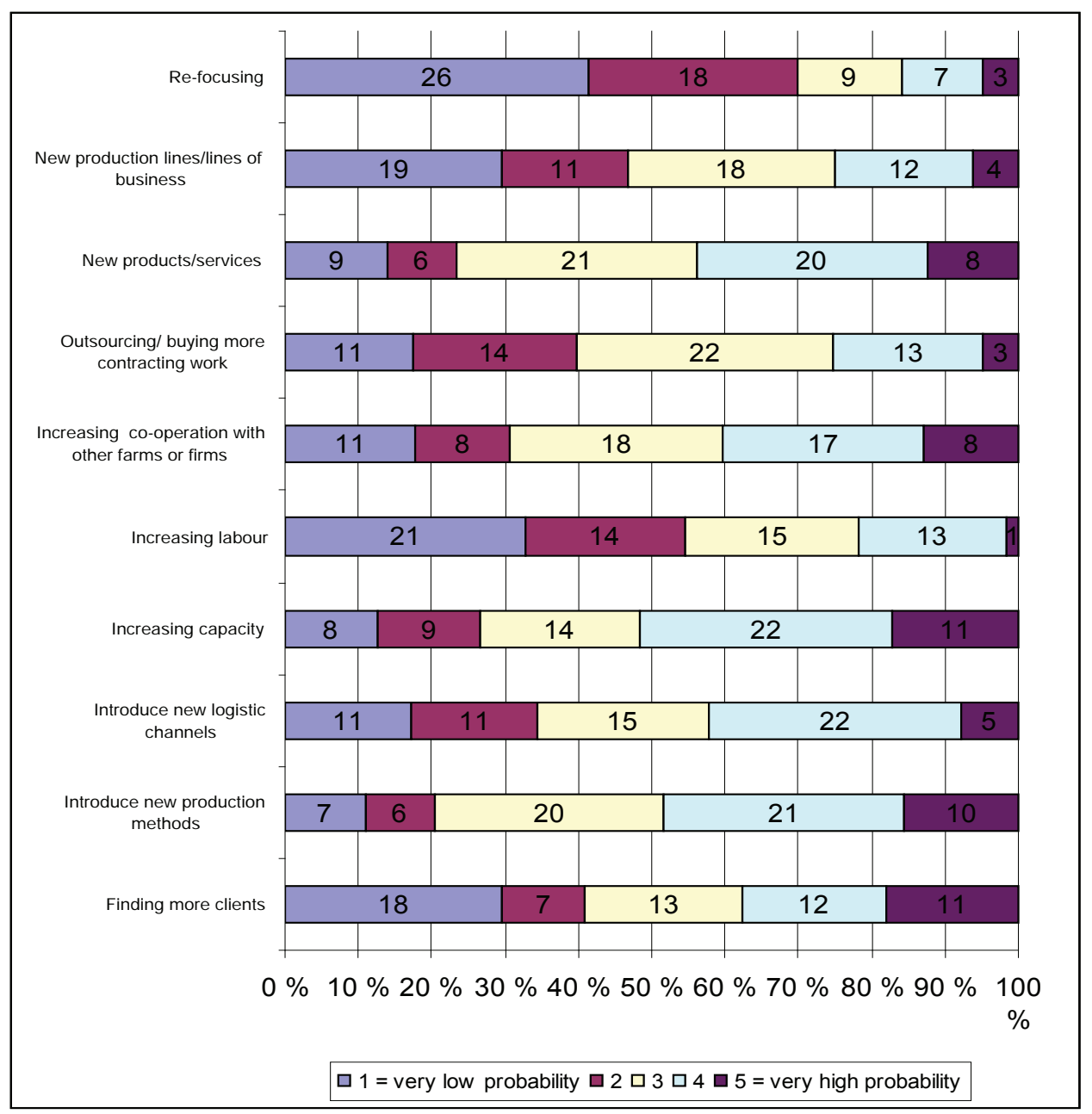

Figure 1. Development plans of the early phase farmers in 2010-2015.

Another noteworthy finding of these data was that many farmers in late phase did not have any development plans for their farm. We analyzed the late phase group further and found no differences between farms that were planning a succession within next five years to those that had no such plans. The result contradicts findings of Gasson and Errington (1993), Mäkinen (2010), Inwood and Sharp (2012) and Wheeler et al. (2012), by which farm families with a successor have a pressing incentive to develop their farms. Thus, according to those authors the absence or presence of a successor may have more influence upon business objectives and farm performance than the age of a farmer. Unfortunately, a specific question about the existence of a successor was not posed in the questionnaire used in our study.

Finally, as there has been controversy about the need for new practices and modes of action, we analyzed the opinions of farmers about networking and their own networking skills (Table 5). The results indicate that early phase farmers are better equipped in this regard than older farmers. Moreover, early phase farmers valued networking more highly than other groups, creating networks was easier for them and they also felt that they had better networks than their older counterparts in the other two groups. This result corresponds to the earlier findings of Goldberg (1996). 
Table 5. Opinions of farmers about networking (scale 1-5, 1 = strongly disagree, 5 = strongly agree)

\begin{tabular}{lllll}
\hline & Early phase & Middle phase & Late phase & $p$-value \\
\hline Networks are important to my enterprise & 3.83 & 3.59 & 3.33 & 2.74 \\
It is easy to create networks & 3.06 & 3.12 & 2.93 & $* *$ \\
At the moment my enterprise has good networks & 3.45 & 3.93 & \\
$* *=p<0.01$, Kruskall-Wallis non-parametric test & &
\end{tabular}

\section{Discussion}

The aim of this paper was to analyse how farmers that had recently started running their own farm businesses differ from more experienced farmers in some key farm management areas such as farm and farmer characteristics, strategic objectives and development plans. In the study, farmers were divided in to three different groups according to age, experience; early phase, middle phase and late phase of the farmer. Similarly, in their study Ondersteijn et al. (2003) corrected the age factor by taking account the stage in the family-farm life cycle when analysing the effects of farmer characteristics on their goals.

Due to the regional nature of the survey and the subjective nature of used multivariate analysis methods, the results of the study cannot be generalised as such to the whole population of European or even to Finnish farms of other regions. However, the results are representative of the farmers of one of Finland's most important agricultural areas in terms of the amounts of agricultural output produced and agricultural area utilised. Thus, the results are important in national perspective when developing the viability of rural enterprises. Agriculture in Salo is also economically important as measured by the income and subsidy flows into the region. The great importance of the farming sector in the Salo region is due to its strong agricultural tradition and also it having the best agricultural production conditions in Finland. One specific feature of Salo region is the big share of plant production farms. This may also have some influences on the study results. However, the problems faced and possibilities found by farmers in the consolidation phase do exist in real-life decision-making regardless of the production line or the location of the farm.

According to our results, farmers in early phase are, in certain respects, better equipped than those of older colleagues. In general farmers in the early phase of succeeding to a business have better education and better networks than their older colleagues. The results of this study support the earlier findings of the importance of networks upon the entry phase of the firm or farm. Moreover, the younger entrepreneurs consider their networks to be generally more important than their senior colleagues. It was found that the farmers in the early phase group invested more and had more liabilities. Their farms were also less profitable than the others.

Strategic management objectives were similar for all the entrepreneurial phases. However, farmers in the early phase valued economic objectives slightly more than their older counterparts, whereas they valued social actions, environment responsibility-objectives and work satisfaction-objectives less than did the others. In general, early phase farmers considered their performance to be somewhat weaker than others when evaluating how they achieved the goals set. In the study, early phase farmers were the most active at developing their farms. The late phase farmers were the least active. Even the farmers that were going to transfer their farm to the next generation within the next five years did not have other development plans. The result contradicts earlier findings of Gasson and Errington (1993) by which farm families with a successor have a pressing incentive to develop their farms. Thus, according to those authors the absence or presence of a successor may have more influence upon business objectives and farm performance than the age of a farmer. This particular result was quite problematic from the point of view of the successor because each generation needs to make big investments immediately after taking over the farm. Thus, the life cycle of the farm should be separated from the lifecycle of the entrepreneur (farm family). When the farms were developed continuously, also the viability of the whole farming sector would improve.

During the time of survey, the market situation was very poor and price relationship extremely unfavorable. With no doubt this has affected also the farmers' opinions on their economic performance and farm profitability. Furthermore, the increasing insecurity caused by price volatility and changes in market prices may be seen as one of the major problems for farms developing their production or planning future succession. 
Wheeler et al. (2012) point out, that successions are strongly influenced by farm type and context. In the future studies, the meaning of production line should be taken into account better than it was possible in this study. In this research most of the respondents were crop farmers. In many other studies (e.g. Mäkinen 2010) focus is on animal husbandry farms. It seems like many older farmers in our data have chosen to follow stagnation strategy (see Kuhmonen 2012). It raises a question if there are significant differences on decision-making between different production lines. It might also be that crop farmers react differently to policy changes than farmers with animal husbandry. As the share of crop farms in the total farm population is increasing, this information is needed when future rural and agricultural policies are planned or implemented.

\section{References}

Cuykendal, C., LaDue, E. \& Smith, D.R. 2002. What successfull small farmers say. The results of a survey of successful small farm operators. R.B. 2002-01. Ithaca, New York: Agricultural Finance and Management at Cornell.

Diwisch, S., Voithofer, P. \& Weiss, C. 2009. Succession and firm growth: results from non-parametric matching approach. Small Business Economics (1)32: 45-56.

Gasson, R. \& Errington, A. 1993. The Farm Family Business. CAB International. 290 p.

Goldberg, S.D. 1996. Research Note: Effective Successors in Family-Owned Businesses: Significant Elements. Family Business Review 9(2): 185-197.

Hair, J., Anderson, R., Tatham, R. \& Black, W. 1998. Multivariate data analysis. $5^{\text {th }}$ edition. USA: Prentice-Hall International. 730 p.

Hirvi, T. 2004a. Aktiivitilojen viljelijöiden mielipiteitä investointituesta ja nuorten viljelijöiden aloitustuesta. MTT:n selvityksiä 79. 60 p. (in Finnish).

Hirvi, T. 2004b. Nuorten viljelijöiden tulonmuodostus ja työnkäyttö. MTT:n selvityksiä 65. 66 p. (in Finnish).

Inwood, S.M. \& Sharp, J.S. 2012. Farm persistence and adaptation at the rural-urban interface: Succession and farm adjustment. Journal of Rural Studies 28: 107-117.

Kimhi, A. \& Lopez, R.A. 1999. Note on Farmers' Retierement and Succession Considerations: Evidence from a Household Survey. Journal of Agricultural Economics 50: 154-162.

Kuhmonen, T. 2012. Maatilayrityksen strategiat ja innovaatiot. Tutu julkaisuja 1/2012. 56 p. In: http://ffrc.utu.fi/julkaisut//tutusarja/Tutu_2012-1.pdf. (in Finnish).

Littunen, M., Storhammar, E.\& Nenonen, T. 1998. The survival of firms over the critical first years and the local environment. Entrepreneurship \& Regional Development 10: 189-202.

Mäkinen, H. 2010. Maatilojen menestyminen ja kehittämisstrategiat, Maataloustieteen päivät 2010. In: Hopponen, A. (ed.). Maataloustieteen Päivät 2010. Suomen Maataloustieteellisen Seuran julkaisuja no 26. Available on the internet: http://www. smts.fi. (in Finnish).

Nalson, J.S. 1968. Mobility of Farm Families. Manchester University Press.

Niemi, J. and Ahlstedt, J. (eds.) 2011. Finnish agriculture and rural industries 2011. Agrifood Research Finland. Economic Research. Publications 111a. 96 p.

Ondersteijn, C.J.M, Giesen, G.W.J. \& Huirne, R.B.M. 2003. Identification of farmer characteristics and farm strategies explaining changes in environmental management and environmental and economic performance of dairy farms. Agricultural Systems 78 : 31-55.

Rantamäki-Lahtinen, L. 2007. Hajauttamisen pitkän aikavälin vaikutukset monialaisilla tiloilla -vertailututkimus Suomesta ja Englannista. In: Juntti, L. ja Rantamäki-Lahtinen, L. (eds.). 2007. Monialaisuus maaseutuyrityksen mahdollisuutena. MTT:n selvityksiä 145. 62 p. (in Finnish).

Salon kaupunki. 2011. Maatalouden kehittämisohjelma 2011-2020. 19 p. (in Finnish).

Wheeler, S., Bjornlund, H., Zuo, A. \& Edwards, J. 2012. Handing down the farm? The increasing uncertainty of irrigated farm succession in Australia. Journal of Rural Studies 28: 266-275.

Weiss, C.R. 1999. Farm Growth and Survival: Econometric Evidence for Individual Farms in Upper Austria. American Journal of Agricultural Economics 81: 103-116.

Väre, M. 2007. Determinants of farmer retirement and farm succession in Finland. Agrifood Research Reports 93. Agrifood Research Finland. $109 \mathrm{p}$.

Väre, M. 2010. Sukupolvenvaihdokset ja Lutu-järjestelmä. In: Hopponen, A. (ed.). Maataloustieteen Päivät 2010. Suomen Maataloustieteellisen Seuran julkaisuja no 26. Available on the internet: http://www.smts.fi. (in Finnish). 


\section{Appendix 1.}

\section{Quick Cluster}

Initial Cluster Centers

\begin{tabular}{|l|c|c|c|}
\hline \multirow{2}{*}{} & \multicolumn{3}{|c|}{ Cluster } \\
\cline { 2 - 4 } & 1 & 2 & 3 \\
\hline Age & 16.00 & 54.00 & 59.00 \\
Entrepreneurial experience & 10.00 & 42.00 & 11.00 \\
\hline
\end{tabular}

Iteration History

\begin{tabular}{|c|c|c|}
\hline \multirow{2}{*}{ Iteration } & \multicolumn{2}{|c|}{ Change in Cluster Centers } \\
\cline { 2 - 3 } & 1 & 2 \\
\hline 1 & 17.139 & 9.841 \\
3 & 3.540 & 2.323 \\
4 & 0.671 & 0.748 \\
5 & 0.511 & 0.245 \\
6 & 0.157 & 0 \\
\hline
\end{tabular}

a. Convergence achieved due to no or small change in cluster centers. The maximum absolute coordinate change for any center is 0.000 . The current iteration is 6 . The minimum distance between initial centers is 31.401 .

Final Cluster Centers

\begin{tabular}{|l|c|c|c|}
\hline \multirow{2}{*}{} & \multicolumn{3}{|c|}{ Cluster } \\
\cline { 2 - 4 } & 1 & 2 & 3 \\
\hline Age & 37.28 & 57.48 & 47.67 \\
Entrepreneurial experience & 5.09 & 29.34 & 17.36 \\
\hline
\end{tabular}

Number of Cases in each Cluster

\begin{tabular}{|ll|c|}
\hline Cluster & 1 & 64 \\
& 2 & 93 \\
& 3 & 86 \\
Valid & & 243 \\
Missing & & 8 \\
\hline
\end{tabular}


Appendix 2.

Communalities

\begin{tabular}{|l|c|c|}
\hline & Initial & Extraction \\
\hline Living countryside & 0.341 & 0.377 \\
Independent work & 0.525 & 0.761 \\
Independent work & 0.509 & 0.607 \\
Good quality work & 0.456 & 0.463 \\
Respecting nature & 0.259 & 0.242 \\
Being able to get independent income & 0.429 & 0.524 \\
Domestic production & 0.397 & 0.456 \\
Economic profitability & 0.484 & 0.662 \\
Continuing family farm & 0.376 & 0.431 \\
Better standard of living & 0.424 & 0.443 \\
Profit maximising & 0.356 & 0.461 \\
Extraction Method: Principal Axis Factoring. & & \\
& & \\
\hline
\end{tabular}

Factor Matrix ${ }^{\mathrm{a}}$

\begin{tabular}{|l|c|c|}
\hline \multirow{2}{*}{} & \multicolumn{2}{|c|}{ Factor } \\
\cline { 2 - 3 } & 1 & 2 \\
\hline Living countryside & 0.703 & -0.327 \\
Independent work & 0.670 & -0.302 \\
Independent work & 0.632 & -0.050 \\
Good quality work & 0.627 & -0.161 \\
Respecting nature & 0.584 & -0.207 \\
Being able to get independent income & 0.541 & -0.027 \\
Domestic production & 0.534 & -0.206 \\
Economic profitability & 0.497 & 0.427 \\
Continuing family farm & 0.450 & 0.036 \\
Better standard of living & 0.536 & 0.612 \\
Profit maximising & 0.443 & 0.571 \\
Extraction Method: Principal Axis Factoring. & \\
\hline
\end{tabular}

a. 3 factors extracted. 21 iterations required.

Factor Transformation Matrix

\begin{tabular}{|c|c|c|c|}
\hline Factor & 1 & 2 & 3 \\
\hline 1 & 0.653 & 0.592 & 0.472 \\
2 & -0.330 & -0.339 & 0.881 \\
3 & 0.682 & -0.731 & -0.025 \\
\hline
\end{tabular}

